Jerzy Rychlik

\title{
Realizacja praw mniejszości białoruskiej w Polsce i mniejszości polskiej na Białorusi
}

\section{Mniejszość białoruska w Polsce}

\section{Liczebność i rozmieszczenie}

Białorusini to mniejszość narodowa tradycyjnie zamieszkała na terenach województwa podlaskiego. Podczas przeprowadzonego w $2011 \mathrm{r}$. narodowego spisu powszechnego ludności i mieszkań narodowość białoruską zadeklarowało 43878 obywateli (w 2002 r. - 47 640). Największe skupiska mniejszości białoruskiej znajduja się w południowo-wschodnich powiatach województwa podlaskiego, tj. w powiecie hajnowskim $(39,2 \%)$, bielskim $(19,8 \%)$, siemiatyckim $(3,46 \%)$, białostockim $(3,2 \%)$. $\mathrm{Na}$ terenie 12 gmin województwa podlaskiego przedstawiciele mniejszości białoruskiej stanowia ponad $20 \%$ mieszkańców gminy, w tym w czterech ponad 50\%, tj. w gminie Czyże (powiat hajnowski, około $81 \%$ ludności), w gminie Dubicze Cerkiewne (powiat hajnowski, około $81 \%$ ), w gminie orlej (powiat bielski, około 68\%), w gminie Hajnówka (powiat hajnowski, około 84\%). Mniejszość białoruska stanowi obecnie druga pod względem liczby ludności mniejszość narodowa w Polsce. Ustępuje jedynie pod tym względem mniejszości niemieckiej, która według narodowego spisu powszechnego ludności i mieszkań w 2011 r. wynosiła 144236 osób ${ }^{1}$.

\section{Białorusini w II RP}

Prawa mniejszości narodowych w II RP chroniły umowy międzynarodowe i wewnętrzne ustawy polskie. Wśród zobowiązań międzynarodowych, które dotyczyły ludności białoruskiej w Polsce, należy

${ }^{1}$ Dane za GUS: Narodowy spis powszechny ludności i mieszkań 2011 rok, Warszawa 2012. 
wymienić traktaty wersalski i ryski. W myśl postanowień tzw. małego traktatu wersalskiego ${ }^{2}$ wszyscy mieszkańcy państwa polskiego stawali sie Polakami, członkami zorganizowanego narodu. W związku z tym traktat operował jedynie pojęciami: „mniejszości rasowe, religijne i językowe”. Wszyscy, którzy zamieszkiwali w granicach państwa polskiego i należeli do mniejszości, byli traktowani jak obywatele polscy. Ochrone mniejszości białoruskiej w dwudziestoleciu międzywojennym zapewniały konstytucje: przepisy Konstytucji marcowej i kwietniowej. Zawierały one wcześniejsze ustalenia zamieszczone w małym traktacie wersalskim. W stosownej ustawie użyty został termin „mniejszości narodowe” obok „wyznaniowych”, co było niewątpliwie różnica wobec leksyki traktatu. Władze godziły się na pełny i swobodny rozwój właściwości narodowościowych, mniejszości, tworzenie autonomicznych związków mniejszości o charakterze publiczno-prawnym w obrębie związku samorządu powszechnego. Postanowienia traktatu ryskiego podzieliły białoruski obszar etniczny na część zachodnią, która znalazła się w granicach Polski (w piśmiennictwie białoruskim obszar ten powszechnie nazywany jest również współcześnie Białorusią Zachodnią oraz Wschodnią, która utworzyła Białoruską Socjalistyczną Republikę Radziecką). Białorusini w II Rzeczpospolitej żyli głównie na terenie województwa poleskiego, białostockiego, nowogródzkiego i wileńskiego. Według spisu ludności z 1931 r. jako Białorusini zadeklarowało się w przybliżeniu 995 tys. osób, a jako Poleszucy - 580 tys. osób. Według Alfonsa Krysińskiego i Wiktora Orfickiego zamieszkane wówczas przez ludność białoruska tereny można podzielić na trzy obszary, w zależności od panujących na nich proporcji narodowościowych:

- zwarty obszar białoruski, m.in. powiat nowogródzki, baranowicki, słonmski, nieświeski;

- zwarty obszar białorusko-polski, m.in. powiaty województwa wileńskiego, tj. powiat brasławski, powiat wileński, powiat oszmiański oraz powiaty województwa białostockiego, tj. powiat wołkowyski, bielski i grodzieński;

- mieszany obszar białorusko-ukraiński, tj. południowa część województwa poleskiego będąca pasem granicznym między zwartym obszarem białoruskim i ukraińskim ${ }^{3}$.

228 VI 1919 r. Polska ratyfikowała traktat wersalski i wraz z nim wyraziła zgodę na podpisanie odrębnego dokumentu, tzw. małego traktatu wersalskiego, który regulował obowiązku rządu wobec mniejszości.

${ }^{3}$ J. Tomaszewski, $Z$ dziejów Polesia, zarys stosunków społeczno-ekonomicznych, Warszawa 1963, s. 69 i n. 
Białorusini w II RP w przeważającej mierze byli ludnością rolniczą. Odsetek Białorusinów utrzymujący się z pracy na roli wynosił około $92 \%$. Ludność białoruska żyła na ogół w trudnych warunkach ekonomicznych, zamieszkane przez nią województwa cechowały się bowiem zazwyczaj niska klasa gleb oraz prymitywna technika uprawy roli. Na zamieszkiwanych przez Białorusinów terytoriach panowała niemal gospodarka naturalna. W odróżnieniu od społeczności ukraińskiej nie tworzyli oni tak rozwiniętego systemu organizacji społecznych i gospodarczych. W wyborach do Sejmu w listopadzie 1922 r. kandydaci białoruscy startowali w ramach bloku mniejszości narodowych. Do Klubu Białoruskiego weszło 11 posłów i 3 senatorów. Znaleźli się w nim przedstawiciele białoruskiej chadecji, socjaldemokracji i bezpartyjni. W 1924 r. powstało związane z ruchem chrześcijańsko-społecznym Białoruskie Zjednoczenie Chrześcijańsko-Demokratyczne. Do ruchu ludowego odwoływał się przede wszystkim Białoruski Związek Włościański. Dużo jednak większe znaczenie odgrywał Ruch Socjalistyczny. Polityczną potęga stała się utworzona w 1925 r. Białoruska Włościańska-Robotnicza Chromada. Działając przez stosunkowo krótki okres (1925-1927), osiagnęła ona liczbe ponad 100 tys. członków. Chromada próbowała rozwijać działalność również na terytorium znajdującym się we współczesnych granicach terytorium Polski. Według niepełnych danych objęła ona swoim działaniem m.in. około 100 miejscowości powiatu Bielsk Podlaski. Silne komitety tej partii istniały również w Białowieży, Orli i Kleszczelach. Na przeszkodzie rozwoju białoruskiej aktywności społecznej i politycznej stał fakt, iż od początku lat 30. władze II RP znacznie nasilały kontrole wobec wszelkich przejawów białoruskiego życia narodowego.

Szkolnictwo białoruskie w okresie II RP znajdowało się w najgorszej sytuacji spośród wszystkich zamieszkałych w Polsce mniejszości narodowych. Do najważniejszych ustaw regulujących oświatę białoruską należała ustawa zawierająca niektóre postanowienia o organizacji szkolnictwa z 31 lipca 1924 r. Precyzowała ona warunki tworzenia szkół z niepolskim językiem nauczania. Podstawa do ubiegania się o zorganizowanie szkoły $\mathrm{z}$ wykładowym językiem ruskim, białoruskim lub litewskim było zamieszkiwanie na obszarze, gdzie ludność niepolska stanowiła co najmniej $25 \%$ obywateli oraz deklaracje 40 opiekunów prawnych dzieci w tej sprawie. Jeżeli chodzi o szkoły średnie z językiem białoruskim, to wspomniana ustawa zezwalała na tworzenie dwujęzycznych państwowych szkół średnich ogólnokształcących na podstawie stwierdzonego urzędowo żądania rodziców 150 uczniów. W 1926 r. $\mathrm{w}$ stosownych przepisach zaakceptowano egzamin dojrzałości w języku białoruskim. Sieć białoruskich gimnazjów w II RP obejmowała głównie szkoły prywatne w Wilnie, Nowogródku, Gródku i Nieświerzu. 
Istotnym problemem szkół białoruskich była kadra pedagogiczna. Nauczyciele szkół powszechnych z językiem białoruskim początkowo uzyskiwali kwalifikacje zawodowe podobnie jak pozostali nauczyciele. Po ukończeniu siedmioklasowej szkoły powszechnej wstępowali do pięcioletniego seminarium nauczycielskiego, a następnie odbywali dwuletnią praktykę kończaca się egzaminami teoretycznymi i praktycznymi. W 1930 r. otwarte zostało państwowe Polsko-Białoruskie Seminarium Nauczycielskie im. Franciszka Bohusiewicza w Wilnie. W praktyce jednak oświata wśród mniejszości białoruskiej była prowadzona w znikomym procencie. Mniejszość białoruska bowiem liczyła blisko 1,5 mln osób. Funkcjonowały natomiast tylko 3 szkoły z ojczystym językiem wykładowym, tj. białoruskim, w których uczyło się około 500 uczniów. W latach 30. nastapiło dalsze osłabienie się pozycji szkolnictwa białoruskiego. I tak w roku szkolnym 1934/1935 funkcjonowało jeszcze 16 powszechnych szkół białoruskim, w 1936/1937 - 8, w 1937/1938 - już żadna ${ }^{4}$.

\section{Organizacje mniejszości białoruskiej w Polsce}

W porównaniu ze stowarzyszeniami polskiej mniejszości narodowej organizacje mniejszości białoruskiej należą do najbardziej skoncentrowanych terytorialnie. Wydane w 2010 r. opracowanie Głównego Urzędu Statystycznego zaznaczało, iż 10 z 12 stowarzyszeń Białorusinów ma swoje zarządy w Białymstoku. W sumie stowarzyszenia białoruskie zrzeszaja około 5,5 tys. członków ${ }^{5}$. Zdecydowana większość tej grupy przypada na Białoruskie Towarzystwo Społeczno-Kulturalne. Jest ono najstarsza organizacja białoruska w Polsce, zarejestrowane w 1956 r. Do 1988 r. była to jedyna organizacja mniejszości białoruskiej w Polsce. Do głównych celów działalności Towarzystwa należy m.in.: działalność na rzecz rozwijania białoruskiej świadomości narodowej, umacnianie więzi przyjaznego współżycia ludności białoruskiej z narodem polskim, wszechstronne propagowanie wiedzy o Republice Białorusi oraz organizowanie twórczości artystycznej, kulturalnej i naukowej mniejszości białoruskiej w Polsce. Towarzystwo ma swoje oddziały również i poza białostocczyzna, m.in. w Warszawie i Gdańsku. Warto nadmienić, że również w 1956 r. na Uniwersytecie Warszawskim utworzono filologie białoruska, co powszechnie odbierano jako znacząca podstawe do zaistnienia białoruskiej elity intelektualnej.

\footnotetext{
${ }^{4}$ Mniejszości narodowe w Polsce - informator $1994 \mathrm{r}$.

${ }^{5}$ Opracowanie GUS, Warszawa $2010 \mathrm{r}$.
} 
W 2006 r. zostało utworzone Towarzystwo Kultury Białoruskiej, które kontynuuje wiele imprez kulturalnych organizowanych uprzednio przez Białoruskie Towarzystwo Społeczno-Kulturalne, m.in. konkurs recytatorski „Ojczyste Słowo”. Od 15 marca 1993 r. działa również Związek Białoruski Rzeczypospolitej Polskiej. Jest to organizacja skupiajaca wiele stowarzyszeń białoruskich o charakterze twórczo-zawodowym: Białoruskie Stowarzyszenie Literackie „Białowieża”, Białoruskie Towarzystwo Historyczne, Stowarzyszenie Dziennikarzy Białoruskich, Rade Programowa „Niwa”, Białoruskie Zrzeszenie Studentów, Białoruskie Towarzystwo „Chatka” oraz partie polityczna Białoruskie Zjednoczenie Demokratyczne. Do Związku Białoruskiego nie należą Białoruskie Towarzystwo Społeczno-Kulturalne, Towarzystwo Kultury Białoruskiej i Związek Młodzieży Białoruskiej. W zakres działania Związku Białoruskiego należą sprawy dotyczące mniejszości białoruskiej, począwszy od spraw lokalnych, na współdziałaniu z władzami państwa kończąc. Związek sprawuje również pieczę nad szkolnictwem białoruskim oraz organizuje seminaria historyczne i literackie.

Białoruskie Zrzeszenie Studentów powstało w latach 80. jako organizacja opozycyjna wobec Białoruskiego Towarzystwa Społeczno-Kulturalnego. Nieformalnie Zrzeszenie działało już od jesieni 1981 r., ale oficjalnie zostało zarejestrowane w listopadzie w 1988 r. Zrzeszenie nawoływało do zreformowania Białoruskiego Towarzystwa Społeczno-Kulturalnego i uczynienia z niego organizacji reprezentującej interesy społeczności białoruskiej na Białostocczyźnie. Od 1990 r. organizuje corocznie Festiwal Muzyki Młodej Białorusi („Basowiszcza”). Od kwietnia 1992 r. Zrzeszenie Studentów współpracuje ze Związkiem Młodzieży Białoruskiej. W 1993 r. Związek po raz pierwszy zorganizował Festiwal Poezji Śpiewanej i Piosenki Autorskiej „Jesień Bardów”. W latach 1993-1996 organizacja ta działała w ramach Związku Białoruskiego Rzeczpospolitej Polskiej.

Kolejną organizacja, która powstała w 1990 r., jest Białoruskie Stowarzyszenie Literackie „Białowieża”. Stowarzyszenie to powstało z inicjatywy grupy literackiej, funkcjonującej od 1958 r. przy Białoruskim Towarzystwie Społeczno-Kulturalnym. Swoje działania koncentruje na popularyzowaniu kultury białoruskiej. Stowarzyszenie zrzesza wielu twórców białoruskich znanych w Polsce, m.in. Nadzieję Artymonowicz, Wiktora Szweda, Sokrata Janowicza, Mire Łukasza oraz Jana Czykwina, który jest przewodniczącym Stowarzyszenia. Interesy dziennikarzy i publicystów środowiska białoruskiego od 1992 r. reprezentuje Stowarzyszenie Dziennikarzy Białoruskich, które wydaje miesięcznik o charakterze społeczno-kulturalnym „Czasopis”. 
W 1992 r. zarejestrowano Radę Programowa Tygodnika „Niwa”. W jej skład wchodza wszyscy przedstawiciele organizacji białoruskich poza Białoruskim Towarzystwem Społeczno-Kulturalnym i Towarzystwem Kultury Białoruskiej. Białoruskie Towarzystwo Historyczne zajmuje sie upowszechnianiem wiedzy historycznej o Białorusinach oraz kształtowaniem postaw tolerancji. Towarzystwo działa od $1993 \mathrm{r}$. Organizacja ta wydaje „Białoruskie Zeszyty Historyczne”.

Poza wymienionymi na rzecz mniejszości białoruskiej w Polsce działają również inne liczne organizacje, wśród których warto wymienić Stowarzyszenie „Muzeum i Ośrodek Kultury Białoruskiej w Hajnówce" (prowadzi Muzeum Białoruskie w Hajnówce oraz organizuje imprezy promujące kulture mniejszości białoruskiej), Stowarzyszenie „Villa Sokrates” (organizujące coroczną konferencję naukową Trialogi Białoruskie), Stowarzyszenie „Muzeum Małej Ojczyzny” w Studziwodach (prowadzace skansen w Studziwodach oraz organizujace liczne imprezy promujące tradycyjny folklor mniejszości białoruskiej Podlasia) czy też stowarzyszenie na rzecz dzieci i młodzieży uczącej się języka białoruskiego „AB-BA”, wspierające nauczanie języka białoruskiego w Białymstoku ${ }^{6}$.

\section{Działalność kulturalna mniejszości białoruskiej w Polsce}

Do największych imprez kulturalnych organizowanych przez mniejszość białoruska należą: Festiwal Muzyki Młodej Białorusi „Basowiszcza”, Festiwal „Piosenka Białoruska” w Białymstoku, Festiwal Piosenki Śpiewanej i Piosenki Autorskiej „Jesień Bardów”, Międzynarodowy Festiwal Kulturalny „Siabrouskaja Biasieda”, Święto Kultury Białoruskiej w Białymstoku, Święto „Kupalle” w Białowieży, Polsko-Białoruskie Warsztaty Literackie „Biazmieżża” oraz Konkurs Poezji i Prozy „Debiut”. Ponadto organizowany jest szereg imprez o charakterze lokalnym. Większość z nich jest dofinansowywana z budżetu państwa i tak np. w 2007 r. na działania służące podtrzymaniu i rozwojowi kultury mniejszości białoruskiej z budżetu MSWiA wydano łączną kwotę ponad 1 mln 900 tys. zł. W 2008 r. minister spraw wewnętrznych i administracji skierował w tym celu podobna kwotę, zaś w 2009 r. już ponad 2 mln 85 tys. zł. Obecnie sprawami mniejszości narodowych zajmuje się minister administracji i cyfryzacji ${ }^{7}$.

${ }^{6}$ Szerzej na temat. zob. J. Kalina, Biatorusini $w$ Polsce $w$ prasie, radio $i$ telewizji (1956-2008), [w:] T. Zaniewska (red.), Białorusini, Warszawa 2010, s. 63-76.

${ }^{7}$ Zob. szerzej J. Tomalska, Pejzaż wymarzony - twórczość artystów białoruskich w Polsce po II wojnie światowej, [w:] Biatorusini, s. 109-120. 


\section{Mniejszość białoruska w polskich mediach}

Pierwsza audycja w języku białoruskim pojawiła się 13 czerwca 1958 r. na antenie radia „Białystok”. Audycja ta nosiła nazwę Biełaruski Mahazin. Trwała 15 min i nadawana była raz albo dwa razy w tygodniu. Obecnie radio „Białystok” emituje codziennie program w języku białoruskim pod nazwą Pod znakiem Pogoni, a raz w tygodniu nadawany jest również program Pażadalnaja pieśnia. Oprócz tego na antenie radia nadawane są audycje religijne. Od 1999 do 2002 r. działało również radio „Racja”, które swoje programy kierowało do odbiorców w Polsce i na Białorusi. Radio „Racja” starało się pełnić rolę w pełni niezależnego i obiektywnego środka przekazu, który komentuje bieżące wydarzenia na Białorusi i świecie. W lutym 2006 r. po blisko czteroletniej przerwie dzięki dotacji rządu RP radio „Racja” wznowiło swoją działalność. Mniejszość białoruska ma również swój program telewizyjny, który nadaje ośrodek białostocki TVP. Cotygodniowy program Tydzień białoruski poświęcony jest problemom i istotnym wydarzeniom mniejszości białoruskiej w Polsce. W marcu 1997 r. na antenie OTVP „Białystok” pojawił się magazyn o mniejszościach narodowych Sami o sobie. Na 30-minutową składały się części w jezzykach: białoruskim, litewskim, ukraińskim, litewskim oraz felietony o Romach, Tatarach, Niemcach i Polakach na wschodzie. Redagowane w języku polskim. Dyrekcja ośrodka powołała radę konsultacyjną przy programie Sami o sobie, składająca się z przedstawicieli stowarzyszeń skupiajacych te narodowości. Do jej kompetencji należała ocena merytoryczna audycji. Program od poczatku tworzyli dziennikarze wywodzący się z poszczególnych grup narodowych, znajacy języki i uwarunkowania społeczno-kulturowe regionu. Program od początku był też tłumaczony za pomoca napisów na język polski. Po dwóch latach czas emisji magazynu zwiększono do 40 min. Powstał też samodzielny magazyn Łaczy nas Polska, traktujacy o Polakach na Litwie, Łotwie, Białorusi, Ukrainie i Rosji. Jego oglądalność szacowana na około 80 tys. widzów, co dawało mu druga pozycje po codziennym programie informacyjnym Obiektyw. O jakości programu może świadczyć fakt, że na I Międzynarodowym Festiwalu Filmów i Programów Telewizyjnych o Mniejszościach Narodowych „U siebie" w Krakowie w 1997 r. otrzymał I nagrodę przyznawana przez dziennikarzy zajmujących się tematyką etniczną w całej Europie.

Białoruska mniejszość narodowa w Polsce znalazła również swoje miejsce w programie satelitarnej telewizji Belsat TV, która rozpoczęła nadawanie 10 grudnia 2007 r. Projekt tej pierwszej niezależnej białoruskiej stacji telewizyjnej był przygotowywany w Telewizji Polskiej od czerwca 2006 r. Przy realizacji projektu Telewizja Polska współpracowała m.in. z członkami Białoruskiego Stowarzyszenia Dziennikarzy oraz środowiskiem Białoruskich Dziennikarzy w Polsce. 
Od początku projektu jest wspierany również przez Fundację „Wolność i Demokracja" (organizacja non-profit realizująca projekty na rzecz demokracji na Białorusi). Telewizja Belsat TV powstała jako odpowiedź na zgłaszane przez środowiska demokratyczne w Republice Białoruś zapotrzebowanie na niezależna informację, rozrywkę i ofertę kulturalną. Mieszkańcom Białorusi mającym utrudniony dostęp do własnego języka i dziedzictwa narodowego Belsat służy jako wypełnianie luki informacyjnej i kulturowej, która pozostawiają dostępne w Białorusi stacje i kanały telewizyjne - czyli Białoruska Telewizja Państwowa. Językiem nadawania Belsatu jest białoruski. Rolą Belsatu jest również promowanie wśród Białorusinów znajomości własnej kultury narodowej i historii, co jest szczególnie ważne w związku ze zwalczaniem przez obecne władze większości przejawów białoruskiego patriotyzmu i budowania świadomości obywatelskiej ${ }^{8}$.

Ze względu na podobne doświadczenia historyczne Polski projekt spotkał się z poparcie MSZ i Rządu RP. W ramach prowadzonej przez Polskę polityki wsparcia międzynarodowej współpracy na rzecz demokracji i społeczeństw obywatelskich. Jest to największy tego typu projekt pomocowy w Europie. Uzyskał ówcześnie aprobate głównych sił politycznych w parlamencie. Projekt Belsat TV został wsparty przez Departament Stanu USA oraz MSZ Litwy. Na Litwie przygotowywane sa programy publicystyczne, m.in. Forum oraz Pocztówka $z$ Wilna. Belsat współpracuje również z radiem „Swabada” (sekcja białoruska radia „Wolna Europa” z siedziba w Pradze). Dziennikarze tej stacji przygotowuja dla Belsatu program publicystyczny. Kanał podpisał także umowę z niemiecka telewizja „Deutsche Welle”, która bezpłatnie udostępnia programy dotyczace wydarzeń społeczno-kulturalnych w krajach Unii Europejskiej. Wspólnie z radiem „Racja” jest tworzony cotygodniowy przegląd prasy białoruskiej Press-Express. Belsat TV na swej antenie promuje również najważniejsze białoruskie imprezy w Polsce. Część operatorów sieci telewizji kablowej na Podlasiu ma ten kanał w bezpłatnej ofercie programowej.

\section{Oświata białoruska w Polsce}

Zarządzenie zezwalajace na tworzenie szkół białoruskich w Polsce, głównie w Białostockiem, resort oświaty Polskiego Komitetu Wyzwolenia Narodowego wydał 3 października 1944 r. W roku szkolnym 1944/1945 utworzono w sumie 93 szkoły, w których prowadzone było nauczanie języka białoruskiego. Jednak początkowo przychylna polityka

\footnotetext{
${ }^{8}$ Zob. J. Kalina, Biatorusini..., s. 63-76.
} 
władz polskich zmieniła się już w następnym roku szkolnym. Nie przeprowadzono bowiem rekrutacji do klas pierwszych w szkołach średnich. Pretekstem do likwidacji szkolnictwa białoruskiego stała się akcja wymiany ludności (władze twierdziły, iż w obliczu wyjazdów ludności białoruskiej nie będzie potrzeby funkcjonowania tego typu szkół). Szkołom białoruskim zarzucano ponadto brak lojalności wobec państwa polskiego. W szybkim tempie zmniejszała się liczba szkół powszechnych oraz zlikwidowano trzy szkoły średnie - gimnazjum w Hajnówce, Bielsku Podlaskim i Białymstoku. W rezultacie takiej polityki liczba szkół zmniejszyła się w ciagu trzech kolejnych lat z 93 do 6. W 1949 r. sytuacja jednak uległa poprawie. Ówczesne Ministerstwo Oświaty poleciło, aby w miejscowościach zamieszkanych przez ludność białoruską uruchomić z dniem 1 września 1949 r. szkoły podstawowe z białoruskim językiem nauczania. W roku szkolnym 1949/1950 ponownie uruchomione dwie szkoły średnie z językiem białoruskim, tj. w Hajnówce i Bielsku Podlaskim. Mimo, iż oficjalnie szkoły te miały status placówek z białoruskim językiem nauczania, to $\mathrm{z}$ powodu nieznajomości języka białoruskiego przez nauczycieli większość przedmiotów wykładana była w języku polskim. Od początku lat 60. tych liczba szkół z białoruskim językiem wykładowym systematycznie malała na korzyść szkół z nauczaniem tego języka jako jednego $\mathrm{z}$ przedmiotów. W rezultacie podstawowa formą białoruskiego szkolnictwa stała się szkoła z językiem białoruskim nie jako wykładowym, a zaledwie przedmiotem dodatkowym. Przełomowym dla białoruskiego szkolnictwa w powojennej Polsce był rok szkolny 1971/1972. był on ostatnim, w którym formalnie istniały jeszcze szkoły podstawowe z białoruskim językiem nauczania. Od roku szkolnego 1972/1973 istniały już tylko szkoły, w których język białoruski był nauczany jako przedmiot dodatkowy. Silnie odbiło sie na szkolnictwie mniejszości białoruskiej zwłaszcza rozporządzenie Ministerstwa Oświaty z 22 lutego 1971 o dobrowolności nauki języka białoruskiego. Nakaz corocznego sporządzania przez rodziców deklaracji wyrażających wole posłania dziecka na lekcje języka białoruskiego okazał się przyczyną rezygnacji z nauczania tego przedmiotu w wielu dotychczasowych placówkach ${ }^{9}$.

\section{Szkoła białoruska w III RP}

Aktualną podstawe prawną do organizowania nauczania z językiem białoruskim w szkołach i przedszkolach jest stosowne rozporządzenie Ministra Edukacji Narodowej ${ }^{10}$ z 14 listopada 2007 r. Zainteresowani

${ }^{9}$ Zob. E. Romanowska, Szkoła białoruska w Polsce od czasów II po III Rzeczpospolita, [w:] Biatorusini, s. 76-83.

${ }^{10}$ Dz.U. 2007, nr 214, poz. 1579. 
rodzice (prawni opiekunowie) powinni złożyć w tej sprawie jednorazowo, na zasadzie dobrowolności, pisemne oświadczenie do dyrektora przedszkola lub szkoły przy zgłoszeniu dziecka do takiej placówki. Nauczanie z językiem białoruskim w szkołach podstawowych organizowane jest przy przynajmniej 7 zgłoszonych uczniach w przedszkolu, szkole podstawowej i gimnazjum, a w szkołach ponadgimnazjalnych - przy co najmniej 14 uczniach. Jeżeli dzieci objętych wnioskiem jest mniej, organizowane sa grupy międzyoddziałowe na poziomie danej klasy przy minimalnej liczbie 7, a w przypadku szkół ponadgimnazjalnych - 14 osób lub grup międzyklasowych. Za zgodę właściwego organu prowadzacego liczba uczniów w oddziałach grup międzyoddziałowych lub międzyklasowych może być mniejsza niż przewiduje zarządzenie. Istnieje również możliwość zorganizowania zespołów międzyprzedszkolnych i międzyszkolnych w wymiarze trzech godzin tygodniowo, przy minimalnej liczbie trzech i maksymalnej liczbie 20 uczniów.

Niemniej należy stwierdzić, że obecnie nie istnieją szkoły podstawowe ani średnie, w których używany byłby język białoruski jako wykładowy. Praktycznie rzecz biorac, nie istnieje edukacja przedszkolna. W zasadzie język białoruski bywa jedynie nauczany jako jeden z przedmiotów szkolnych w wymiarze trzech godzin lekcyjnych tygodniowo. Komitet Ekspertów Rady Europy uznał taką formę nauczania język białoruskiego za niezgodna z podjętymi przez Rzeczypospolitą Polska zobowiązaniami i wezwał władze polskie do podjęcia działań mających na celu udostępnienie oświaty w języku białoruskim na poziomie podstawowym i średnim w celu zapewnienia dostępności oświaty na terenach, na których jest używany język białoruski. W uwagach do raportu Komitetu Ekspertów rząd polski stanął na stanowisku, iż przepisy oświatowe zapewniają taką możliwość, natomiast brak przedszkoli i szkół prowadzacych edukację w języku białoruskim wynika z braku zapotrzebowania na taka formę nauczania.

Zarówno w roku szkolnym 2009/2010, jak i 2010/2011 zajęcie z języka białoruskiego prowadzone były ogółem w 39 szkołach (w tym $22 \mathrm{w}$ szkołach podstawowych, 14 gimnazjach i 3 liceach ogólnokształcących). W roku szkolnym 2009/2010 na zajęcia z języka białoruskiego uczęszczało 3067 uczniów, a w roku szkolnym 2010/2011 liczba spadła do 2921. Liczba uczęszczających uczniów na zajęcia z języka białoruskiego systematycznie spada. Wynika to z przyczyn demograficznych, a także wyjazdu części Białorusinów z obszarów województwa podlaskiego w inne rejony Polski. Największe znaczenie dla białoruskiej oświaty na poziomie ponadgimnazjalnym maja dwa licea, których historia siega jeszcze lat 40. ubiegłego wieku: Liceum Ogólnokształcące z Dodatkową Nauka Języka Białoruskiego w Hajnówce oraz Liceum 
Ogólnokształcące z Białoruskim Językiem Nauczania im. Bronisława Taraszkiewicza w Bielsku Podlaskim. Z tych właśnie szkół wywodzi się większość uczniów przystępujących do matury z języka białoruskiego. Są one również instytucjami oświatowymi najbardziej rozpoznawalnym w gronie przedstawicieli opisywanej mniejszości. Do szkół tych ze względu na ich wysoki poziom nauczania uczęszcza również młodzież polska. Do egzaminu maturalnego z języka białoruskiego w maju 2009 r. przystąpiło 240 maturzystów. Większość, bo 212 , zdawała egzamin na poziomie podstawowym. Do egzaminu na poziomie rozszerzonym przystapiły 2 osoby. Pozostałe 26 osób to laureaci olimpiady języka białoruskiego, którzy byli zwolnieni z egzaminu maturalnego i na świadectwie mieli wpisany wynik maksymalny. W roku 2010 do matury z języka białoruskiego na poziomie podstawowym przystapiły 264 osoby, 25 osób było laureatami olimpiady z języka białoruskiego. Egzamin maturalny z języka białoruskiego w 2011 r. zdawało 290 osób z czego 264 na poziomie podstawowym. Do egzaminu na poziomie rozszerzonym przystapił 1 uczeń, pozostałe 25 osób to laureaci olimpiady przedmiotowej ${ }^{11}$.

\section{Udział mniejszości białoruskiej w życiu politycznym Polski}

W połowie kwietnia 1989 r. środowisko białoruskie podjęło decyzję powołaniu własnego Białoruskiego Komitetu Wyborczego i samodzielnym udziale w wyborach do Sejmu i Senatu 4 czerwca 1989 r. Kandydatem białoruskiego Komitetu Wyborczego do Senatu był wówczas Sokrat Janowicz, który zdobył 22,5 tys. głosów (8,5\%). 10 lutego 1990 r. odbył się założycielski kongres Białoruskiego Zjednoczenia Demokratycznego. Partia nigdy nie odniosła jednak sukcesu wyborczego ani nie cieszyła się dużym poparciem wśród elektoratu, do którego się odwoływała. Ze względu na aprobate dla przeobrażeń ustrojowych Białoruskie Zjednoczenie Demokratyczne postrzegane było przez miejscowych Białorusinów nie jako ich własna partia mogaca realizować ich interesy, ale jako partia sympatyzująca z ówczesną władzą związaną z Solidarnością. Białoruskie Zjednoczenie Demokratyczne przetrwało do 2005 r., kiedy to partie wykreślono $\mathrm{z}$ ewidencji partii politycznych. Należy jednak zauważyć, że do tej pory pozostaje jedyna partia mniejszości narodowej w III RP. W wyborach do parlamentu w $1991 \mathrm{r}$. w okręgu białostocko-suwalskim rywalizowały ze soba dwie listy odwołujące się do głosów mniejszości narodowej: Białoruski Komitet Wyborczy utworzony przez Białoruskie Zjednoczenie Demokratyczne oraz Komitet Wyborczy Prawosławnych

${ }^{11}$ Informacje uzyskane w Departamencie Współpracy z Polonia i Polakami za Granica MSZ (materiał niepublikowany). 
popierany przez organizacje bliskie Cerkwi. Okazało się, że rozproszony i zdezorientowany przez powstanie dwóch konkurencyjnych list elektorat zwrócił się gremialnie nie ku własnym działaczom, a ku liście SLD. $\mathrm{Na}$ Komitet Wyborczy Prawosławnych zagłosowało wówczas 13788 osób $(4,3 \%)$, co pozwoliło na uzyskanie mandatu Eugeniuszowi Czykwinowi. Białoruski Komitet Wyborczy otrzymał w okręgu dużo mniejszą lecz głosów, bo tylko 4435 (1,4\%). Kolejne wybory do parlamentu, w 1993 r., zakończyły się fiaskiem Białorusinów. Komitet Wyborczy Związku Białoruskiego otrzymał ponownie zaledwie czteroprocentowe poparcie, a w parlamencie nie znalazł sie żaden przedstawiciel społeczności prawosławnej i Białostocczyzny, co było zasadniczym ciosem dla idei startu Białorusinów z samodzielnych list wyborczych.

Przedstawiciele mniejszości białoruskiej sprawowali po $1989 \mathrm{r}$. mandaty poselskie. Nie byli jednak wybierani z listy samodzielnego komitetu wyborczego, jak np. przedstawiciele mniejszości niemieckiej, a reprezentowali z reguły ogólnopolski Sojusz Lewicy Demokratycznej i tak np. latach 1993-2001 mandat poselski w Sejmie drugiej i trzeciej kadencji z ramienia SLD sprawował Sergiusz Plewa. W latach 1997-2001 w Sejmie zasiadał przewodniczacy BTSK Jan Syczewski. W trakcie wyborów w 2001 r. organizacje mniejszości białoruskiej popierały wybranych na posłów Eugeniusza Czykwina i Aleksandra Czuża oraz Sergiusza Plewe - wszyscy otrzymali mandaty z listy SLD-UP. W wyborach do podlaskiego sejmiku wojewódzkiego w 2002 r. na liste Białoruskiego Komitetu Wyborczego majacego być alternatywa zwłaszcza dla cieszącego się dużym poparcie podlaskich mniejszość SLD oddano 15544 głosy (4,11\%). Najwięcej głosów zebrali Sokrat Janowicz, Jan Czykwin oraz Eugeniusz Wagpa.

Kontrowersje wzbudził podział na okręgi wyborcze, w których powiaty z dużą liczbą mniejszości połączono razem z powiatami etnicznie polskimi o silnych sympatiach prawicowych, np. powiat siemiatycki i bielski połaczone zostały w jeden okręg wyborczy z powiatami wysokomazowieckim i zambrowskim. W wyborach parlamentarnych w 2005 r. mandat poselski udało się uzyskać jedynie Eugeniuszowi Czykwinowi, który zdobył 14181 głosów. Mandat polityk ten zdobywał jeszcze w wyborach z 2007 i 2011 r. (podobnie około 14 tys. głosów) i jest obecnie jedynym przedstawicielem mniejszości białoruskiej w polskim parlamencie. W wyborach do podlaskiego sejmiku województwa w 2006 r. na Białoruski Komitet Wyborczy oddano 7914 głosów (2,05\%). Najwięcej głosów z tej listy zdobyli Jan Czykwin, Eugeniusz Wagpa i Eugeniusz Mironowicz. Mimo że BKW nie uczestniczył w podziale mandatów, to ostatecznie w składzie sejmiku znalazło się trzech radnych z mniejszości białoruskiej. Przedstawiciele mniejszości znaleźli się również 
w składach rad miejskich. W Białymstoku cztery mandaty uzyskali kandydaci z Forum Mniejszość Podlasia, którzy wystartowali z list Platformy Obywatelskiej. W Bielsku Podlaskim 7 mandatów w 21-osobowej Radzie Miasta zdobyła złożona z organizacji białoruskich koalicja bielska. W Hajnówce 6 mandatów w 21-osobowej radzie przypadło Białorusko-Ludowemu Komitetowi Wyborczemu. Białorusko-Ludowy Komitet Wyborczy bioracy udział w wyborach w powiecie hajnowskim wprowadził 4 przedstawicieli do Rady Powiatu oraz 38 osób do poszczególnych rad gmin, w tym obsadził wszystkie mandaty w Radzie Gminy Czyże. W wyborach do podlaskiego sejmiku w 2007 r. Białoruski Komitet Wyborczy poparło 2,19\% głosujacych. Obok Białorusinów z list Białoruskiego Komitetu Wyborczego wystartowali wtedy również po raz pierwszy przedstawiciele mniejszości litewskiej.

Kryzys samodzielnego startu Białorusinów w wyborach samorządowych w województwie podlaskim nastąpił w 2010 r. Białorusini nie tylko nie wystawili wówczas własnego komitetu w wyborach do sejmiku wojewódzkiego, ale nawet w powiecie hajnowskim nie powołano własnego Białorusko-Ludowego Komitetu Wyborczego odnoszącego sukcesy w szeregu poprzednich wyborach. Jego dotychczasowi działacze odeszli do list innych komitetów (koalicja wyborcza „Ziemia hajnowska”, Platforma Obywatelska, PSL). Kandydaci należacy do mniejszości startowali zatem z list zarówno ogólnokrajowych partii politycznych, jak i lokalnych komitetów wyborczych. W wyniku wyborów kandydaci należący do mniejszości w obecnie funkcjonujących radach gmin i powiatów województwa podlaskiego zamieszkałych przez mniejszość białoruska oraz w sejmiku województwa. W gminach zamieszkałych przez zwarte skupiska mniejszości białoruskich kandydaci należący do mniejszości pełnią funkcje wójtów gmin. Przedstawiciele mniejszości białoruskiej pełnią także funkcję starostów i wicestarostów w niektórych powiatach województwa podlaskiego zamieszkałych przez warte skupiska osób należących do tej mniejszości ${ }^{12}$.

\section{Życie religijne}

Zdecydowana większość przedstawicieli mniejszości białoruskiej należy do Polskiego Autokefalicznego Kościoła Prawosławnego. Pozostali sa głównie katolikami. Prawosławni Białorusini mieszkaja głownie na terenie dwóch diecezji: warszawsko-bielskiej i białostocko-gdańskiej.

${ }^{12}$ Raport nt. mniejszości narodowych $w$ Polsce, opracowanie MSWiA, 2011; zob. też E. Mironowicz, Białorusini w wyborach parlamentarnych $i$ samorzadowych $w$ Polsce w latach 1989-1994, „Białowieskie Zeszyty Historyczne” 1995, t. IV, s. 121-131. 
Polski Autokefaliczny Kościół Prawosławny jest drugim co do wielkości Kościołem w Polsce. Ogólną liczbę wiernych szacuje się na około 600 tys. Kościół posiada 6 diecezji, 21 dekanatów i 243 parafie. Pracuje w nim 260 duchownych. Stosunki Kościoła z państwem reguluje ustawa z 4 lipca 1991 r. O stosunku Państwa do Polskiego Autokefalicznego Kościoła Prawostawnego ${ }^{13}$.

Nabożeństwa odbywają się w języku starocerkiewnosłowiańskim, kazania natomiast wygłasza się w języku polskim bądź rosyjskim.

\section{Kwestie językowe}

Postulatem zgłaszanym od kilku lat przez mniejszość białoruska było przywrócenie historycznego brzmienia, w wersji białoruskiej, nazw wsi na Białostocczyźnie oraz wprowadzenie dwujęzycznych nazw topograficznych na terenach zamieszkałych w większości przez Białorusinów. Zagadnienia te zostały uregulowane w przyjętej przez Sejm $\mathrm{RP}$ w dniu 6 stycznia 2005 r. ustawie $O$ mniejszościach narodowych $i$ etnicznych oraz o języku regionalnym ${ }^{14}$. Ustawa wprowadza możliwość używania obok urzędowych nazw miejscowości i obiektów fizjograficznych oraz nazw ulic dodatkowych tradycyjnych nazw w języku mniejszości. Dodatkowa nazwa miejscowości lub obiektu fizjograficznego w języku mniejszości może być ustalona na wniosek rady gminy, jeżeli liczba mieszkańców tej gminy należących do mniejszości nie jest mniejsza niż 20\% ogólnej liczby mieszkańców tej gminy (w przypadku mniejszości białoruskiej kryterium to spełnia 12 gmin województwa podlaskiego) lub gdy z ustaleniem dodatkowej nazwy w języku mniejszości opowiedziała się ponad połowa mieszkańców miejscowości biorących udział w konsultacjach. Ustawa dopuszcza również możliwość stosowania języków mniejszości jako języków pomocniczych w gminach, w których liczba mieszkańców gminy należących do mniejszości jest nie mniejsza niż $20 \%$ ogólnej liczby mieszkańców gminy.

Dnia 3 grudnia 2007 r. do Urzędowego Rejestru Gmin, w których używany jest jezzyk pomocniczy, wpisana została pierwsza gmina, w której językiem pomocniczym został język białoruski (Hajnówka). Do chwili obecnej do Rejestru wpisano cztery kolejne gminy (Orla, Narewka, Czyże, gmina wiejska Hajnówka), w których językiem pomocniczym został język białoruski. Dnia 17 maja 2010 r. do MSWiA wpłyną pierwszy wniosek gminy zamieszkałej przez mniejszość białoruska o wpisanie do Rejestru Gmin, na których obszarze używane sa nazwy

\footnotetext{
${ }^{13}$ Dz.U. 1991, nr 66, poz. 287, ze zm.

${ }^{14}$ Dz.U. 2005, nr 17, poz. 141, ze zm.
} 
w języku mniejszości. Wniosek złożyła gmina Orla. Wniosek został pozytywnie zaopiniowany przez Komisje Nazw, Miejscowości i Obiektów Fizjograficznych. Gmina Orla została wpisana do Rejestru.

Mając na uwadze potrzebę promowania wśród mniejszości białoruskiej używania przed organami gminy języka białoruskiego, jako języka pomocniczego oraz używania dodatkowych tradycyjnych nazw miejscowości w tym języku, Minister Spraw Wewnętrznych i Administracji zdecydował się wesprzeć w 2008 r. w trybie ustawy z 24 kwietnia 2003 r. $O$ działalności pożytku publicznego $i$ o wolontariacie kwota 5 tys. zł, służące tym celom zadanie realizowane przez Związek Młodzieży Białoruskiej w środowisku mniejszości białoruskiej na Podlasiu.

W dniu 18 marca 2002 r. Minister Spraw Wewnętrznych i Administracji wydał rozporządzenie w sprawie wypadków, w których nazwom i tekstom w języku polskim moga towarzyszyć wersje w przekładzie na język mniejszości.

Obywatele polscy należacy do mniejszości narodowych i etnicznych zgodnie z polskim ustawodawstwem moga dokonywać zmiany imienia i nazwiska na wersje zgodna z brzmieniem i pisownia języka ojczystego w trybie administracyjnym, na podstawie ustawy z 17 października 2008 r. O zmianie imienia i nazwiska ${ }^{15}$. Zmiany pisowni imion i nazwisk można dokonywać w urzędach stanu cywilnego właściwych dla miejsca zamieszkania. Prawo osób należących do mniejszości do używania i pisowni swoich imion i nazwisk zgodnie z zasadami pisowni języka mniejszości, w szczególności do rejestracji w aktach stanu cywilnego dokumentów tożsamości, zostało także zagwarantowane w ustawie z 6 stycznia 2005 r. O mniejszościach narodowych $i$ etnicznych oraz języku regionalnym.

\section{Stosunki z państwem - uregulowania prawne}

Najważniejszym aktem prawa wewnętrznego, którego przepisy dotycza mniejszości narodowych, jest Konstytucja RP. Zgodnie z art. 35. Konstytucji RP, Rzeczpospolita Polska zapewnia obywatelom polskim należącym do mniejszości narodowych i etnicznych wolność zachowania i rozwoju własnej kultury. Mniejszości narodowe i etniczne maja prawo do tworzenia własnych instytucji edukacyjnych, kulturalnych i instytucji służących ochronie tożsamości religijnej oraz do uczestnictwa w rozstrzyganiu spraw dotyczących ich tożsamości kulturowej. W dniu 6 stycznia 2005 r. Sejm RP uchwalił ustawę $O$ mniejszościach

${ }^{15}$ Dz. U. 2008, nr 220, poz. 1414; więcej na temat zmian pisowni imion i nazwisk zob. M. Chmaj, Prawo administracyjne materialne, Warszawa 2010, s. 199-201. 
narodowych $i$ etnicznych oraz języku regionalnym. Ustawa zawiera odniesienia do wszystkich zasad zawartych w Konwencji ramowej Rady Europy o ochronie mniejszości narodowych. Obejmuje katalog praw przysługujących mniejszościom narodowym i etnicznym, zakaz dyskryminacji z powodów narodowych bądź etnicznych oraz zakaz asymilacji. W gminach, w których liczba mieszkańców gminy należących do mniejszości jest nie mniejsza niż $20 \%$ ogólnej liczby mieszkańców gminy, ustawa dopuszcza możliwość stosowania języków mniejszości jako języków pomocniczych przed organami gminy. Wprowadzenie języka pomocniczego daje przedstawicielom mniejszości prawo do zwracania sie do organów gminy w języku pomocniczym w formie pisemnej bądź ustnej i na wyraźne życzenie uzyskiwania od nich odpowiedzi w tym języku. Ustawa wprowadza możliwość używania obok urzędowych nazw miejscowości i obiektów fizjograficznych oraz nazw ulic dodatkowych tradycyjnych nazw w języku mniejszości. Ustawa gwarantuje także prawo urzędowego zapisywania imion zgodnie z zasadami języka ojczystego mniejszości. Odrębny rozdział ustawy poświęcony oświacie i kulturze zawiera regulacje związane $\mathrm{z}$ nauka języka i w języku ojczystym mniejszości oraz zasady dotyczące finansowania działalności kulturalnej mniejszości narodowych i etnicznych. Ustawa wprowadziła również zmiany do ustawy o radiofonii i telewizji, ustalajac zadania publicznej radiofonii i telewizji wobec mniejszości narodowych i etnicznych.

Na mocy przepisów ustawy została utworzona Komisja Wspólna Rządu i Mniejszości Narodowych i Etnicznych, będąca organem opiniodawczo-doradczym Prezesa Rady Ministrów. W skład Komisji wchodzą przedstawiciele mniejszości narodowych i etnicznych oraz społeczności posługujące się językiem regionalnym, a także przedstawiciele organów administracji rządowej. Reprezentantami mniejszości białoruskiej w Komisji sa Jan Syczewski i Eugeniusz Wappa. Prawa mniejszości narodowych i etnicznych zostały zapisane również $\mathrm{w}$ wielu innych aktach prawnych. Regulacje dotyczace praw mniejszości białoruskiej znalazły się także w polsko-białoruskich umowach dwustronnych. W dniu 23 czerwca 1992 r. został zawarty Traktat między Rzeczapospolitą Polska a Republika Białoruś o dobrym sąsiedztwie i przyjaznej współpracy ${ }^{16}$, w którym prawom mniejszości poświęcone sa art. 13-17. Kwestie dotyczące upamiętnień reguluje umowa między Rządem Rzeczypospolitej Polskiej a Rządem Republiki Białoruś o ochronie grobów i miejsc pamięci ofiar wojen i represji, sporządzona w Brześciu dnia 21 stycznia 1995 r. ${ }^{17}$ Sprawy mniejszości narodowych znalazły również odzwiercie-

\footnotetext{
${ }^{16}$ Dz.U. 1993, nr 118, poz. 527.

${ }^{17}$ Dz.U. 1997, nr 32, poz. 185.
} 
dlenie w zapisach Umowy między Rządem Rzeczypospolitej Polskiej a Rządem Republiki Białoruś o współpracy w dziedzinie nauki, kultury i oświaty, podpisanej 27 listopada $1995 \mathrm{r}$.

\section{Mniejszość polska na Białorusi}

\section{Liczebność i obszar zamieszkiwania mniejszości polskiej na Białorusi ${ }^{18}$}

Według oficjalnych danych na Białorusi zamieszkuje 396 tys. osób polskiego pochodzenia (wedługg szacunków nieoficjalnych liczba ta jest znacznie większa). Tylko niewielka część z nich - 13,3\% - uznaje język polski za swój język ojczysty (dla porównania: na Litwie $-84,8 \%$, na Ukrainie - 12,5\%). Polacy sa trzecią pod względem liczebności grupa narodową po Białorusinach i Rosjanach, stanowią około 3,9\% ogółu populacji. Skupiska polskie rozmieszczone sa nierównomiernie. Najwięcej Polaków zamieszkuje na Grodzieńszczyźnie - około 294 tys., co stanowi $24,8 \%$ wszystkich mieszkańców obwodu. W samym Grodnie mieszka około 65 tys. Polaków. Większe skupiska ludności polskiej występuja ponadto $\mathrm{w}$ obwodach brzeskim i mińskim oraz rejonie brasławskim w obwodzie witebskim. Pochodzenie osób deklarujących swa przynależność do narodu polskiego jest miejscowe i uzależnione w dużej mierze od przywiązania do „małej ojczyzny”. Osoby młode, posiadające polskie korzenie, najczęściej migruja do miast w poszukiwaniu pracy i lepszych perspektyw życiowych. Efektem tego procesu jest postępujace wynarodowienie i zanik więzi z językiem polskim i tradycją. Ciagle daje się zauważa słabość inteligencji zdolnej do w pełni świadomego i kreatywnego utożsamienia się z narodowością polską. Wśród Polaków na Grodzieńszczyźnie jest dość liczna grupa ludzi wykształconych, posiadających tytuły naukowe, jednakże tylko nieznaczna część z nich uczestniczy w życiu mniejszości polskiej. Charakter skupisk polskich w obwodzie mińskim jest inny niż na Grodzieńszczyźnie i w rejonie brzeskim. Wynika to m.in. z faktu, że tylko nieznaczna część tych ziem znajdowała się w obrębie granic państwa polskiego w okresie międzywojennym. Większymi skupiskami ludności polskiej we wschodniej Białorusi sa miasta Borysów, Witebsk, Mohylew. Mniejsze skupiska ludności

${ }^{18}$ Za Raportem MSZ o sytuacji Polonii i Polaków za granica, 2009; zob. także J. Gajdel, Liczba i rozmieszczenie Polaków na Białorusi radzieckiej w świetle powszechnych spisów ludności w okresie międzywojennym, [w:] E. Skrobacki (red.), Problemy świadomości narodowej ludności polskiej na Białorusi, Grodno 2003, s. 163-178. 
polskiej o charakterze lokalnym występują również na Homelszczyźnie - okolice Lelczyc. W większości sa to potomkowie Polaków, którzy na przestrzeni XIX i XX w. osiedlili sie na tych obszarach. Ich stan świadomości narodowej jest bardzo zróżnicowany, w większości wypadków pozostają oni obojętni na sprawy polskie. Przyczyną takiego stanu rzeczy sa uwarunkowania historyczne, takie jak okresy prześladowań, procesy wynarodawiania, realizowane na masowa skale przez władze carskie i sowieckie.

\section{Akty prawne regulujące kwestię mniejszości polskiej na Białorusi}

Podstawowym aktem prawnym, który przyznaje mniejszości polskiej na Białorusi prawa, jest Konstytucja Republiki Białorusi z 1993 r. Przyznaje ona szereg praw, jak np. równość wobec prawa (art. 14), ochronę dóbr historyczno-kulturowych i duchowych (art. 15), zachowanie swojej tożsamości narodowej (art. 50 ust. 1), posługiwanie się językiem ojczystym, wybór języka porozumiewania się, państwo gwarantuje na mocy prawa swobode języka wychowania dzieci (art. 50 ust. 3). Ponadto Konstytucja w art. 2 stanowi, że człowiek w jego prawach i wolności i gwarancji ich realizacji stanowią najwyższe wartości, cel społeczeństwa i państwa. W art. 30 ust 1 Konstytucji RB, mówi się, że każdy ma zagwarantowane wolności poglądów, przekonań i swobodę ich wyrażania, natomiast w ust. 3 tego artykułu jest mowa, że monopolizacja środków masowego przekazu przez państwo, organizacje społeczne lub indywidualnych obywateli, a także cenzura są niedozwolone.

Białoruś jest również stroną wielu aktów prawa międzynarodowego, które w większym lub mniejszym stopniu dotycza praw mniejszości, m.in. jest strona Międzynarodowego Paktu Praw Politycznych i Obywatelskich z 1996 r. Białoruś przyjęła również fakultatywnie protokół paktu, który przyznaje możliwość występowania do organów ONZ ze skarga indywidualna $\mathrm{w}$ razie naruszenia zagwarantowanych $\mathrm{w}$ nich praw. Białoruś jest członkiem Organizacji Bezpieczeństwa i Współpracy w Europie, co wiąże się z zobowiązaniem do przestrzegania określonych w jej dokumentach standardów dotyczących praw osób należących do mniejszości narodowych. Do 1996 r. Białoruś należała do Rady Europy, stąd wiązały ją akty prawne tej organizacji, w tym np. dotycząca ochrony mniejszości Europejska Karta Języków Regionalnych i Mniejszościowych z 1992 r. ${ }^{19}$ Podstawowym aktem prawa międzynaro-

${ }^{19}$ Por. J. Sozański, Ochrona mniejszości $w$ systemie uniwersalnym, europejskim i wspólnotowym, Warszawa 2002, s. 100 i n. 
dowego zawartego między Polska a Białorusia jest traktat z 23 czerwca 1992 r. o dobrym sassiedztwie i przyjaznej współpracy, który gwarantuje szereg praw mniejszości polskiej na Białorusi i białoruskiej w Polsce (art. $15^{20}$ ). Innym ważnym aktem w tym zakresie jest umowa z 27 listopada 1995 r. zawarta między Rządem RP a Rządem RB o współpracy $\mathrm{w}$ dziedzinie kultury, nauki i oświaty ${ }^{21}$. Umowa ta daje podstawy do nauczania języka polskiego na Białorusi i białoruskiego w Polsce na wszystkich szczeblach, zaczynając od przedszkola, a kończac na wyższych uczelniach, umożliwia ona również wymianę nauczycieli. Równie ważną umowa międzynarodowa jest umowa o ochronie grobów i miejsc pamięci ofiar wojen i represji z 21 stycznia 1995 r. Oprócz tych aktów prawa międzynarodowego także wiele aktów prawa białoruskiego odnosi się do omawianych zagadnień i tak bardzo ważną w tym zakresie jest ustawa z 11 listopada 1992 r. o mniejszościach narodowych, ustawa z 29 października 1991 r. o oświacie w RB, ustawa z 4 czerwca 1991 r. o kulturze w RB, a także ustawa z 19 listopada 1993 r. o prawach dziecka. Przepisy tych ustaw w zasadzie niczym merytorycznie nie odbiegaja od podobnych aktów prawnych w innych państwach europejskich. Były one tworzone na początku państwowości niepodległej Białorusi. Białoruś na początku lat 90 . była swego rodzaju liderem w dażeniu przemian demokratycznych, miała bardzo poprawne stosunki z Polska. To właśnie w Warszawie otworzyła swa pierwszą Ambasadę. Traktat dobrosasiedzki między RP a RB z 1992 r. był jednym z pierwszych, jaki Polska zawarła z sąsiadami.

\section{Pozycja mniejszości polskiej na Białorusi ${ }^{22}$}

Polacy na Białorusi nie stanowią pod względem ekonomicznym i społecznym wyróżniającej się grupy. Poziom wykształcenia jest mocno zróżnicowany. Elity, głównie miejskie, sa dobrze wykształcone, często po studiach Polsce; ukierunkowane na kształcenie dzieci w RP, co postrzegaja jako wielka dla nich szansę. W rzeczywistości małomiasteczkowej czy kołchozowo-wiejskiej jest znacznie gorzej. W szczególnie złej sytuacji materialnej znajduja się osoby starsze. W największym stopniu dotyczy to osób żyjących na prowincji, w mniejszym

${ }^{20}$ Dz.U. 1993, nr 118, poz. 527.

${ }^{21}$ Dz.U. 1996 nr 76, poz. 365.

${ }^{22} \mathrm{Za}$ Raportem MSZ o sytuacji Polonii i Polaków za granica, 2009 r.; por. D. Górecki, Sytuacji ludności polskiej na Litwie i Białorusi, [w:] D. Górecki (red.), Sytuacja ludności polskiej na Wschodzie w świetle obowiazujacego prawa i praktyki, Toruń 2009, s. $125 \mathrm{i} \mathrm{n.}$ 
stopniu mieszkańców większych miast. Sytuacja polityczna Polaków na Białorusi jest bardzo złożona. Z jednej strony Traktat między Rzeczapospolita Polska a Republika Białoruś o dobrym sasiedztwie i przyjaznej współpracy (z 1992 r.) gwarantuje respektowanie międzynarodowych zasad i standardów dotyczących ochrony praw mniejszości narodowych, z drugiej zaś - władze miejscowe i centralne ewidentnie nie przestrzegaja jego zapisów. Nie ma przemocy, prześladowań i dyskryminacji wyłacznie polskiej grupy etnicznej. Jest natomiast przemoc o charakterze systemowo-strukturalnym, wynikajaca z doktryny ideologicznej niedopuszczającej do samorządowego działania grup społecznych. Pozapaństwowe działania sa systemowo ograniczane i paraliżowane przez instytucje władzy. W zachodniej Białorusi działania takie są szczególnie nasilone, co wynika z uwarunkowań historyczno-politycznych, definiowania zachodnich wpływów jako obcych kulturowo i kreowania w świadomości społecznej mieszkańców domniemania, że jest to teren, gdzie moga być formułowane roszczenia zagrażające integralności terytorialnej RB. Polska mniejszość, a zwłaszcza jej elity, podejrzewane sa $-\mathrm{z}$ reguły na potrzeby propagandy - o realizowanie scenariusza politycznego wrogiego wobec państwa i społeczeństwa białoruskiego.

\section{Dwa Związki Polaków na Białorusi ${ }^{23}$}

Od 2005 r. istnieją dwa kierownictwa Związku Polaków na Białorusi. W tym czasie konflikt na osi ZPB-Mińsk osiagnął punkt kulminacyjny. Białoruskie władze zdelegalizowały związek Andżeliki Borys i nakazały przeprowadzenie nowego zjazdu. Na nim wyłoniono nowa władze organizacji z Józefem Łucznikiem na czele. Tej decyzji nie uznały jednak władze polskie. Efektem takiego przebiegu wydarzeń jest istnienie dwóch niezależnych od siebie związków: władzom Związku uznawanego przez Warszawe przewodzi Mieczysław Jaśkiewicz, a przez Mińsk - Mieczysław Łysy.

Większość członków Związku nie pogodziła się z jawnym pogwałceniem niezależności organizacji i pozostała lojalna wobec Andżeliki Borys i jej postanowieniom. Cena, jaka za to zapłacili, była jednak wysoka. Wyroki, grzywny pieniężne, przetrzymywania w areszcie, zastraszenia, wymuszenia i prowokacje to tylko nieliczne nadużycia. Jeden z liderów Związku, a zarazem opozycyjny publicysta, Andrzej Poczobut, spędził trzy miesiace $\mathrm{w}$ areszcie tymczasowym $\mathrm{w}$ czasie postępowania

${ }^{23} \mathrm{Za}$ :http://notabene.org.pl/index.php/sytuacja-polakow-na-bialorusi/[09.01.2013]. 
o znieważenie prezydenta Białorusi. Wówczas proces skończył się wyrokiem w zawieszeniu, ale w czerwcu 2012 r. ponownie postawiono mu ten sam zarzut i uruchomiono kolejne śledztwo, jednocześnie zakazując mu opuszczania Grodna.

Stosunki między Warszawa a Mińskiem uległy zamrożeniu z powodu sankcji, jakie państwa Unii Europejskiej nałożyły na białoruski reżim. Podczas pogarszających się relacji polsko-białoruskich i braku możliwości interwencji ze strony polskiej władze w Mińsku sukcesywnie pozbawiały Związek majątku.

Obecnie znaczna część z domów polskich nie służy już polskiej działalności społecznej, lecz jest wykorzystywana w celach komercyjnych i wynajmowana różnym białoruskim przedsiębiorstwom. W jednym z największych z polskich domów, znajdującym się w Iwieńcu, siedzibę ma obecnie dyrekcja miejscowego kołchozu.

Sytuacja Polaków na Białorusi z politycznego punktu widzenia nigdy nie była łatwa. Ostatnie lata tylko dobitnie tego dowodza. Współcześnie są oni tam traktowani jako element niebezpieczny. Przez lata nie wolno im było się też organizować, co zmienił dopiero upadek komunizmu. W 1990 r. został założony niezależny Związek Polaków na Białorusi.

Należy jednak odróżnić oficjalne stosunki obu państw, i występującą na tej płaszczyźnie niechęć władz białoruskich wobec władz Związku Polaków na Białorusi, od codziennych relacji mieszkańców obu narodów. Zeszłoroczne wybory w ZPB sa dobrą okazją do krótkiego przeanalizowania sytuacji Polaków w Białorusi zarówno w aspekcie politycznym, jak i również społecznym.

Istnienie dwóch Związków Polaków na Białorusi uniemożliwia jednogłośne występowanie z inicjatywami mającymi na celu poprawę sytuacji naszej mniejszości. Dialog Związku Polaków (kierowanego przez Jaśkiewicza) z władzami w Mińsku jest wręcz niemożliwy ze względu na nieuznawanie go przez stronę białoruską.

Związek wciąż nie ma oficjalnej rejestracji, która muszą uzyskać w Ministerstwie Sprawiedliwości organizacje społeczne działające na Białorusi. Mimo usilnych starań ze strony byłej prezes związku, Andżeliki Orechwo, wystosowywanych apeli, listów do prezydenta Łukaszenki z prośbą o legalizację, sprawa ta jeszcze nie doczekała się pomyślnego zakończenia.

Mieczysław Jaśkiewicz zapowiedział, że Związek będzie kontynuował działania swoich poprzedników i będzie wciąż zabiegał o uzyskanie oficjalnej rejestracji. Nowo wybrany prezes nie jest powiązany ze środowiskami białoruskiej opozycji i raczej nie jest tym zainteresowany. 
Może to napawać optymizmem i stanowić okazję do ocieplenia stosunków z białoruską władzą. Z drugiej jednak strony jest bardzo watpliwe, czy w ogóle będą rozpatrywane kolejne wnioski o legalizację organizacji. Przyczyna nieprzychylności do Związku Polaków nie było bowiem żadne konkretne polityczne wydarzenie, a sam fakt jego niezależności.

$\mathrm{Na}$ Białorusi nie ma legalnie działającej polskiej prasy. Maleje liczba polskich duchownych, a co za tym idzie, prawa mniejszości polskiej do nieskrępowanego praktykowania i wyznawania religii w języku ojczystym sa ograniczane. Władze państwowe skutecznie kwestionuja realizowanie postanowień ustawy O Karcie Polaka na terenie Białorusi. Osobom starającym się o taka Karte grozi się utrata pracy. Represje, szykany, przejmowanie dobytku, pozbawienie statusu prawnego to niektóre sytuacje, z którymi muszą sobie radzić polskie organizacje od 2005 r.

Działania Związku Polaków na Białorusi skupiają się przede wszystkim na wspieraniu polskiego szkolnictwa, polskiej tradycji oraz prasy polskojęzycznej. W sytuacji ograniczeń w dostępie do polskiej kultury i jej propagowaniu Związek stawia sobie za cel opracowanie specjalnego programu wspierającego polska oświate i sztukę na Białorusi oraz wzmocnienie istniejaccych ośrodków edukacyjnych.

Mieczysław Jaśkiewicz w swoim pierwszym wystąieniu jako prezes Związku zapowiedział, że będzie zabiegał o dalsze tworzenie przy oddziałach ZPB klas z nauką języka polskiego oraz tworzenie szkół społecznych w miejscach, gdzie nauki języka polskiego nie ma w szkołach państwowych. Planuje też tworzyć nowe oddziały organizacji ${ }^{24}$.

Jeżeli chodzi o prorządowy Związek Polaków na Białorusi, to w latach 2005-2009 jego prezesem był Józef Łucznik, a następnie Stanisław Siemaszko, przestał pełnić tę funkcję w 2012 r. Na tym stanowisku zastąpił go jako p.o. Mieczysław Łysy. 6 kwietnia 2013 r. odbył się w Mińsku kolejny, tj. ósmy, zjazd Związku Polaków na Białorusi i na przewodniczącego wybrano Mieczysława Łysego. Aktualnie według władz probiałoruskiego ZPB (z siedziba w Mińsku) organizacja skupia około 6,5 tys. członków (w latach 90. ZPB liczył około 22 tys. członków), posiada 21 oddziałów i dysponuje 14 Domami Polskimi, które, jak wcześniej nadmieniono, bardzo często sa pewną forma komercjalizacji. Według Mieczysława Łysego naukę języka polskiego w różnych formach pobiera około 10 tys. osób. Organizacja ta nie otrzymuje pomocy finansowej z Polski, całkowicie utrzymuja ja władze białoruskie, tj. z dotacji komitetu ds. religii i mniejszości narodowych. Według danych jest

${ }^{24} \mathrm{http}: / /$ notabene.org.pl/index.php/sytuacja-polakow-na-bialorusi/ [09.01.2013]. 
to aktualnie najwyższa dotacja, jaka otrzymuje tego typu organizacja w RB. Warto jednak zauważyć, że w obradach ostatniego zjazdu ZPB uczestniczył przedstawiciel Ambasady RP w Mińsku²5.

\section{Szkolnictwo polskie}

Nauke języka ojczystego zalicza się do podstawowych praw każdej mniejszości narodowej. Podstawę prawną do nauczania języka polskiego na Białorusi stanowia ustalenia traktatu dobrosasiedzkiego z 1992 r. ${ }^{26}$, który w art. 16 ust. 3 stanowi, iż Białoruś będzie starać się zapewnić mniejszości polskiej możliwość nauki języka ojczystego lub nauczania w tym języku w placówkach oświatowych, a także tam, gdzie jest to możliwe i konieczne posługiwanie się językiem ojczystym wobec władz publicznych. W programach nauczania placówek oświatowych, do których uczęszczają wyżej wymienione osoby, będzie uwzględniona w szerszym zakresie historia i kultura. Także umowa między Rządem RP i RB o współpracy w dziedzinie nauki i kultury z 27 listopada 1995 r. $^{27}$ stanowi, że państwo białoruskie zapewni zainteresowanym osobom na zasadzie dobrowolności dostęp do nauki języka ojczystego i nauki w języku ojczystym w przedszkolach i szkołach różnego stopnia oraz zapewni za obopólna zgoda możliwość podjęcia pracy przez nauczycieli skierowanych do szkół przed drugą z umawiających się stron.

Obecnie od kilku lat wyraźnie spada liczba osób uczących się języka polskiego w szkołach państwowych. Jeszcze w 2007 r. naukę taka pobierało około 18 tys. osób, obecnie liczba ta spadła do około 12 tys. W zasadzie funkcjonuja dwie szkoły polskie - w Grodnie i Wołkowysku, gdzie wszystkie przedmioty powinny być wykładane w języku polskim (bardzo często tak nie jest). W pozostałych szkołach państwowych istnieja klasy z rozszerzonym językiem polskim. Obecnie nasila sie tendencja do likwidowania tych klas nawet w miejscowościach, gdzie mniejszość polska stanowi większość, np. w Nowogródku i Sopoćkach. Występują również trudności w przyjeździe na Białoruś nauczycieli języka polskiego, chociaż mają do tego prawo na mocy stosownych umów. Tak np. w 2012 r. 19 nauczycieli języka polskiego nie otrzymało wiz na Białoruś.

Tego typu sytuacje niepokoja władze polskie. Podczas ostatniego sprawdzianu języka polskiego organizowanego przez Ambasade RP w Mińsku w tej kwestii wypowiedział się ambasador RP. Według niego

${ }^{25}$ Informacja z 7 IV 2007 r. pochodzi ze strony internetowej ZPB.

${ }^{26}$ Dz.U. 1993, nr 118, poz. 527.

${ }^{27}$ Dz.U. 1996, nr 96, poz. 365; por. T. Kruczkowski, Polacy na Białorusi na tle historii i współczesności, Słonin 2003, s. 247-251. 
dwie polskie szkoły (w Grodnie i Wołkowysku) to zdecydowanie za mało dla mniejszości polskiej. Szkoły takie jego zdaniem powinny również powstać np. w Lidzie, Szczuczynie i Worowie ${ }^{28}$. Obok szkół państwowych nauka języka polskiego jest prowadzona również w szkołach społecznych, np. w Baranowiczach (z możliwością uzyskania matury), w domach polskich (chociaż w coraz mniejszym stopniu), w parafiach katolickich czy też klubach. W tym przypadku nie obserwuje się tendencji do spadku zainteresowania językiem polskim, dlatego można sądzić, że nadal nauka języka polskiego cieszy się dużym powodzeniem wśród mniejszości polskiej, a także innych narodowości na Białorusi.

\section{Główne problemy mniejszości polskiej ${ }^{29}$}

Najistotniejsze problemy mniejszości polskiej w RB to:

- Nieuznawanie przez władze RB demokratycznie wybranych władz Związku Polaków na Białorusi, z Mieczysławem Jaśkiewiczem jako prezesem, paraliżowanie działalności statutowej tego ugrupowania, wywieranie presji na jego działaczy. Władze $\mathrm{RB}$, realizujac scenariusz wprowadzenia pełnej kontroli nad społeczeństwem oraz utrwalenia autorytarnego systemu politycznego, sprowokowały w 2005 r. wobec mniejszości polskiej wydarzenia prowadzące do delegalizacji de iure Związku Polaków na Białorusi jako struktury reprezentującej mniejszość polską. W rezultacie zagrożone zostały jej podstawowe interesy w sferze organizowania się oraz realizacji praw kulturalnych i oświatowych. Odmowa prawa działania demokratycznie wybranym władzom Związku Polaków na Białorusi, a także ograniczanie aktywności środowisk polskich, m.in. kulturalno-oświatowej, jest oceniane przez władze polskie jako łamanie praw mniejszości narodowych i praw człowieka.

- Stała presja (inwigilowanie, zastraszanie, ograniczanie swobodnej aktywności, utrudnienia $\mathrm{w}$ prowadzeniu działalności kulturalnej i wydawniczej, swobodnym organizowaniu się, korzystaniu z innych należnych Polakom praw) wywierana przez władze RB na osoby należące do mniejszości polskiej, które pragna realizować swoje prawa zagwarantowane w Traktacie. Niekiedy te ograniczenia znajdują wyraz w aktach legislacyjnych. I tak dekret prezydenta RB z 1 czerwca 2008 r., zatwierdzający zarządzenie o organizacji występów gościnnych i działalności koncertowej, uprawomocnia i tak już istniejące w praktyce

${ }^{28}$ Wypowiedź ambasadora RP zamieszczona na stronie internetowej Ambasady RP w Mińsku - http://minsk.msz.gov.pl/pl/aktualnosci/ii_ogolnobialoruski_sprawdzian_z_jezyka_polskiego [24.05.2013].

${ }^{29}$ Za Raportem MSZ o sytuacji Polonii i Polaków za granica, 2009. 
poważne utrudnienia w organizowaniu wszelkiego rodzaju uroczystości polonijnych, spotkań i koncertów, a w wielu przypadkach wręcz je uniemożliwia. Na porządku dziennym jest na Białorusi, szczególnie na Grodzieńszczyźnie, utrudnianie funkcjonowania organizacji polskich, m.in. poprzez obowiązek corocznego ich rejestrowania, odmowe rejestracji (np. plastykom ze środowiska polskiego), zastraszanie osób aktywnych społecznie.

- Dążenie władz białoruskich do uszczuplenia stanu oświaty w języku polskim i nauczania języka polskiego. Tworzone sa bariery dla przyjazdów nauczycieli z Polski do pracy na Białoruś. Coraz trudniejsze jest uzyskanie dla nich zaproszenia, wizy i pozwolenia na pracę.

- Przejęcie majątku trwałego ZPB, głównie 14 z 18 istniejących domów polskich (w większości zbudowanych z funduszy RP), i przekazanie ich reżimowej organizacji J. Łucznika. Działalność społeczna, kulturalna i oświatowa domów zamarła. Wiele $\mathrm{z}$ nich służy obecnie celom komercyjnym. Zarządy pozostałych pod kontrolą legalnego ZPB domów polskich w Iwieńcu i Baranowiczach sa poddawane nieustannej presji, dokonywane sa ingerencje w skład osobowy zarządów i dobór zatrudnianych tam pracowników, stosowane są wobec nich zaostrzone wymogi formalne i finansowe.

- Stopniowa redukcja liczby polskich duchownych poprzez nieprzedłużanie im prawa do pracy na Białorusi na mocy obowiązujących przepisów wewnętrznych, co może prowadzić do uszczuplenia prawa mniejszości polskiej na Białorusi do swobodnego praktykowania i wyznawania swojej religii.

- Sprzeciw władz białoruskich wobec realizacji ustawy $O$ Karcie Polaka na terytorium RB. Osoby ubiegajace się o Kartę Polaka są inwigilowane zastraszane, np. utrata pracy, i poddawane innym naciskom, np. prowadzone sa przez KGB rozmowy ostrzegawcze z Polakami starającymi się o Kartę Polaka.

\section{Podobieństwa i różnice w realizacji praw mniejszości pol- skiej na Białorusi i mniejszości białoruskiej w Polsce}

\section{Liczba osób i obszar zamieszkiwania}

Zdecydowanie przeważa liczbowo mniejszość polska na Białorusi - około 400 tys. osób, mniejszość białoruska w Polsce to około 43 tys. osób, a więc blisko dziesięciokrotnie mniej. Ludność mniejszości polskiej na Białorusi występuja praktycznie rzecz biorąc na terenie całego państwa z dużym odsetkiem na zachodzie kraju, a szczególnie 
w obwodzie grodzieńskim. Mniejszość białoruska w Polsce to przede wszystkim województwo podlaskie, a w mniejszym stopniu lubelskie, warmińsko-mazurskie i mazowieckie.

\section{Źródła prawa dotyczące praw mniejszości w obu państwach}

Generalnie rzecz biorąc, zarówno w Polsce, jak i na Białorusi kwestia mniejszości jest dobrze uregulowana prawnie. W konstytucjach obu państw znajduja się odpowiednie przepisy oraz zostały przyjęte stosowne ustawy, takie jak o mniejszości narodowej, oświacie, językach czy też kulturze. W zasadzie przepisy tych ustaw niezależnie, czy sa to przepisy ustawy polskiej, czy białoruskiej, zawieraja podobne uregulowania dotyczące mniejszości narodowych - uregulowania spełniające standardy europejskie. Innym ważnym źródłem w realizacji praw mniejszości jest dwustronna umowa międzynarodowa z 1992 r., tzw. traktat dobrosąsiedzki, który w sposób jasny i precyzyjny określa prawa obu mniejszości w obu krajach. Inne umowy bilateralne zawarte między Polską a Białorusią, jak już wspomniana wcześniej umowa z 1995 r. o współpracy w dziedzinie kultury, nauki i oświaty czy też umowa z 1995 r. o ochronie grobów i miejsc pamięci ofiar wojny i represji, także służą realizacji praw mniejszości. Problem polega jednak na tym, że przepisy tych aktów prawych stosuje się bardzo wybiórczo i pomimo korzystnych uregulowań prawych praktyka jest zupełnie inna.

\section{Nauka i stosowanie języka ojczystego}

W obu krajach zgodnie $\mathrm{z}$ obowiąujacymi przepisami prowadzi się nauke języka ojczystego mniejszości, działaja szkoły z tym językiem (dwie polskie na Białorusi i dwie białoruskie w Polsce) oraz szkoły, które prowadzą klasy z językiem ojczystym mniejszości. W obu jednak państwach zauważa się spadek liczby uczniów uczęszczających na lekcje języka ojczystego w szkołach państwowych. W przypadku mniejszości białoruskiej w Polsce wynika to głównie z faktu zmniejszenie się liczebności Białorusinów i ich migracji w inne regiony Polski, zaś w odniesieniu do mniejszości polskiej na Białorusi można mówić o swego rodzaju polityce władz, mającej na celu ograniczenie możliwości nauki języka polskiego. W Polsce statystycznie nauke języka białoruskiego pobiera co 10. osoba wywodząca się z mniejszości białoruskiej, natomiast w przypadku mniejszości polskiej na Białorusi tylko co 30 .

Jeżeli chodzi o kwestie stosowania nazw ulic lub pisania nazwisk w języku ojczystym, to zdecydowania lepiej jest w Polsce. Stosowne 
przepisy prawne dają takie możliwości mniejszości białoruskiej, co przejawia się tym, że np. w niektórych gminach (jak w Hajnówce) wprowadzono oznakowania w języku białoruskim i stosuje się język białoruski jako język pomocniczy. Polskie unormowania daja również prawo do pisania nazwisk w języku ojczystym. Zupełnie odmienne sytuacja wygląda na Białorusi. Język polski nie jest uznawany za język pomocniczy - nie stosuje się nazw w języku polskim, nie ma możliwości pisania nazwisk po polsku. Trudno się temu jednak dziwić, na Białorusi bowiem dominuje język rosyjski. Nawet język białoruski, chociaż jest językiem oficjalnym, bardzo rzadko jest używany w urzędach, nazwach i tytułach.

\section{Organizacje i stowarzyszenia}

Przepisy w obu państwach, a zwłaszcza ustawy o mniejszościach narodowych i stowarzyszeniach, daja prawo do zakładania odpowiednich organizacji i struktur skupiajacych przedstawicieli mniejszości narodowych. Obie mniejszości w większym lub mniejszym stopniu tę możliwość wykorzystuja, a zatem w obu krajach funkcjonują organizacje mniejszości narodowych. Na Białorusi jest to np. Związek Polaków na Białorusi, w Polsce - Związek Białoruski RP oraz szereg innych mniejszych organizacji. Jeżeli chodzi o organizacje mniejszości białoruskiej w Polsce, to sytuacja wydaje się być klarowna, wprawdzie różnia się one między soba, to jednak w istocie tworzą wspólny front działania, uznając się nawzajem. Sa dofinansowywane ze źródeł budżetu $\mathrm{RP}$, a także przez stronę białoruska. Posiadaja własne pomieszczenia i lokale. Ich działalność uznawana jest przez polskie władze.

Inaczej wygląda sprawa w przypadku mniejszości polskiej na Białorusi. W zasadzie funkcjonuja tam pod tą samą nazwa dwa związki Polaków na Białorusi. Jeden - prorządowy, białoruski, nieuznawany przez władze polskie i finansowany przez stronę białoruska, drugi - antyrządowy, nieuznawany przez władze białoruskie, a jedynie przez polskie i finansowany przez strone polska. Oba te związku nie uznaja sie nawzajem. Tego typu sytuacja wpływa negatywnie na konsolidacje i funkcjonowanie mniejszości polskiej na Białorusi.

\section{Bibliografia}

Chmaj M., Prawo administracyjne materialne, Warszawa 2010.

Gajdel J., Liczba i rozmieszczenie Polaków na Białorusi radzieckiej w świetle powszechnych spisów ludności w okresie międzywojennym, [w:] E. Skrobecki (red.), Problemy świadomości narodowej ludności polskiej na Białorusi, Grodno 2003. 
Górecki D., Sytuacja ludności polskiej na Litwie i Białorusi, [w:] D. Górecki (red.), Sytuacja ludności polskiej na Wschodzie w świetle obowiazujacego prawa i prakty$k i$, Toruń 2009.

Kalina J., Białorusini w Polsce w prasie, radio i telewizji (1956-2008), [w:] T. Zaniewska (red.), Biatorusini, Warszawa 2010.

Kruczkowski T., Polacy na Białorusi na tle historii i wspótczesności, Słonim 2003.

Mironowicz E., Białorusini $w$ wyborach parlamentarnych $i$ samorzadowych $w$ Polsce w latach 1989-1994, „Białostockie Zeszyty Historyczne”, t. IV, Białystok 1995.

Raport na temat mniejszości narodowych w Polsce, opracowanie MSWiA.

Raport MSZ o sytuacji Polonii i Polaków za granicą na Białorusi.

Romanowska E., Szkoła białoruska w Polsce od czasów II po III Rzeczpospolite, [w:] T. Zaniewska (red.), Biatorusini, Warszawa 2010.

Sozański J., Ochrona mniejszości w systemie uniwersalnym, europejskim i wspólnotowym, Warszawa 2002.

Tomalska J., Pejzaż wymarzony - twórczość artystów białoruskich w Polsce po II wojnie światowej, [w:] T. Zaniewska (red.), Białorusini, Warszawa 2010.

Tomaszewski J., $Z$ dziejów Polesia, zarys stosunków spoteczno-ekonomicznych, Warszawa 1963.

Wypowiedź ambasadora RP zamieszczona na stronie internetowej Ambasady RP w Mińsku, http://minsk.msz.gov.pl/pl/aktualmnosci/ii_ogolnobialoruski_sprawdzian_z_jezyka_polskiego.

\section{Źródło internetowe}

http://notabene.org.pl/index.php/sytuacja-polaków-na-białorusi. 